\title{
PENGARUH LATIHAN MENYIKAT GIGI TERHADAP KEMAMPUAN MENYIKAT GIGI PADA ANAK TUNAGRAHITA
}

\author{
Sri Wulansari* Ira Faridasari**
}

\begin{abstract}
ABSTRAK
Tunagrahita merupakan istilah untuk menyebut anak atau orang yang memiliki kemampuan intelektual di bawah rata-rata. Anak dengan tunagrahita memiliki ketidakmampuan beradaptasi dan tingkat kemandirian yang kurang. Pendidikan khusus anak tunagrahita untuk membangun kemandirian dan keterlibatannya dalam kehidupan sehari-hari dikenal dengan bina diri. Menyikat gigi merupakan bagian dari bina diri yang harus dikuasai oleh anak, namun masih banyak anak tunagrahita yang tidak mampu menyikat gigi secara mandiri. Kemampuan menyikat gigi anak tunagrahita dapat ditingkatkan dengan berbagai cara, salah satunya dengan memberikan pelatihan menyikat gigi. Tujuan penelitian ini untuk mengetahui pengaruh latihan menyikat gigi terhadap kemampuan menyikat gigi pada anak tunagrahita di SLB C Pancaran Kasih Kota Cirebon tahun 2017. Metode penelitian yang digunakan adalah eksperimen semu dengan one group pretest posttest. Populasi pada penelitian ini yaitu seluruh siswa SD di SLB C Pancaran Kasih data terbaru Agustus 2016 sebanyak 45 siswa. Teknik pengambilan sampel menggunakan purposive sampling, didapatkan jumlah responden yaitu sebanyak 10 anak. Data diperoleh dengan cara observasi dan dianalisis secara statistika menggunakan analisa uji paired t-test, dengan tingkat signifikasi 0,05 .

Hasil penilaian kemampuan anak sebelum dilakukan latihan menunjukkan keseluruhan anak yang mengikuti penelitian ini yaitu sebanyak 10 anak belum mampu menyikat gigi dengan benar. Setelah dilakukan latihan menyikat gigi sebanyak 8 kali selama 2 minggu, anak yang belum mampu berkurang menjadi 4 anak (40\%), dan sebanyak 6 anak (60\%) mampu menyikat gigi dengan benar. Berdasarkan hasil uji simple paired t-test didapatkan hasil pvalue $=0,000$, maka ada pengaruh latihan menyikat gigi terhadap kemampuan menyikat gigi pada anak tunagrahita di SLB C Pancaran Kasih Kota Cirebon Tahun 2017.
\end{abstract}

Kata kunci : tunagrahita, latihan menyikat gigi, kemampuan

\begin{abstract}
Mental retardation is a term used to refer to children or people who have below average of intellectual capacity. Children with mental retardation have an inability in adaptation and have the lowerlevel of independence. Special education for children with mental retardation is known as self-care, that is to make them involve in daily activities and make them realized to take care their life by themselves. Brush tooth is the part of self care, it must be mastered by children, but there are still many children with mental retardation who can't brush their teeth independently. There so many ways to increase the ability brush tooth of children with mental retardation, one of them is giving them about training tooth brushing. The aim of the research is to know theeffectiveness of tooth brushing training of ability brushing tooth in child with mental retardation in SLB C Pancaran Kasih Cirebon city 2017. The method of this research is a quasi experiment with one group pretest posttest design. The population in this research are all elementary school student in SLB C Pancaran Kasih latest data 45 student in August 2016. The sampling technique used purposive sampling found the number of respondents as many as 10 children. Data obtained by observation and analyzed statistically using analysis of paired t-test, with a significance level of 0.05 . The result showed that there are 10 children who not be able to brush their teeth correctly before they had have training about brushing teeth. After they have trained about to brush their teeth in 8 times in 2 weeks, there are $4(40 \%)$ children who not be able brush their teeth, and there are 6 children $(60 \%)$ who be able brush their teeth correctly. Based on a simple test of paired t-test showed the $\mathrm{p}$ value $=0.000$, then there is the effect of training brush tooth of ability brush tooth in child with mental retardation in SLB C Pancaran Kasih Cirebon city 2017.
\end{abstract}

Keyword : Mental retardation, training tooth brushing, ability

\footnotetext{
*Mahasiswa Program Studi S1 Keperawatan STIKes Cirebon

** Staf Pengajar Program Studi S1 Keperawatan STIKes Cirebon
} 


\section{PENDAHULUAN}

Anak merupakan dambaan setiap orang tua. Setiap orang tua mengharapkan anaknya kelak bertumbuh kembang secara optimal baik fisik, mental dan sosial. Tumbuh kembang merupakan proses berkesinambungan yang terjadi sejak anak lahir sampai dewasa. Namun tidak semua anak dapat berkembang secara normal, ada juga anak yang mengalami gangguan dalam proses tumbuh kembangnya.

Anak berkebutuhan khusus menurut Heward adalah anak dengan karakteristik khusus yang berbeda dengan anak pada umumnya tanpa selalu menunjukan pada ketidakmampuan mental, emosi atau fisik. ${ }^{1}$ Istilah lain yang digunakan untuk anak berkebutuhan khusus diantaranya anak tuna, anak menyimpang, anak berkelainan, anak cacat, dan anak luar biasa, ada satu istilah yang berkembang secara luas telah digunakan yaitu difabel, sebenarnya merupakan kependekan dari diference ability. ${ }^{2}$ Yang termasuk kedalam anak berkebutuhan khusus antara lain; tunanetra, tunarungu, tunagrahita, tunadaksa, tunalaras, kesulitan belajar, gangguan perilaku, anak berbakat, anak dengan gangguan kesehatan.

Menurut World Health Organization (WHO) tahun 2007, jumlah anak berkebutuhan khusus di Indonesia sekitar 7-10\% dari total pupulasi anak. Menurut data Badan Pusat Statistik Nasional tahun 2007, terdapat 8,3 juta jiwa anak dengan disabilitas dari total populasi anak di Indonesia (82.840.600 jiwa anak), atau sekitar $10 \% .{ }^{3}$ Populasi orang dengan disabilitas berat tahun 2012 Provinsi Jawa Barat menempati urutan ketiga dari 33 Provinsi di Indonesia dengan jumlah 413.701 jiwa. $^{4}$

Berdasarkan studi pendahuluan yang dilakukan pada tanggal 9 November 2016 di SLBC Pancaran Kasih siswa tunagrahita ringan dan sedang berada dalam kelas yang sama sesuai dengan tingkatan kelas nya. Pendidikan bina diri sudah diterapkan dalam kurikulum pendidikan SLB-C Pancaran Kasih. Praktek bina diri dalam menggosok gigi pernah dilakukan sebelumnya. Menurut informasi guru dan wali kelas SDLB Pancaran Kasih, siswa yang belum bisa menyikat gigi lebih dari setengah jumlah siswa yaitu sekitar 30 dari 45 siswa dan sisanya sebagian sudah mandiri menyikat gigi dan sebagian masih dengan bantuan untuk melakukan kegiatan menyikat gigi. Pendidikan menggosok gigi sangat diperlukan untuk melatih kemandirian pada anak tunagrahita khusus nya untuk anak SDLB dalam bidang merawat dan menjaga kebersihan diri.

Tujuan dalam penelitian ini adalah untuk mengetahui pengaruh latihan menyikat gigi terhadap kemampuan menyikat gigi pada anak tunagrahita di SLB C Pancaran Kasih Kota Cirebon Tahun 2017.

\section{METODE PENELITIAN}

Penelitian ini menggunakan eksperimen semu (Quasi experiment) untuk menguji pengaruh pemberian latihan menyikat gigi terhadap kemampuan menyikat gigi pada anak tunagrahita di SLB C Pancaran Kasih Kota Cirebon Tahun 2017.

Desain penelitian kuasi eksperimen yang digunakan adalah one group pretest posttest yaitu eksperimen yang dilaksanakan pada satu kelompok saja tanpa kelompok pembanding. Penelitian ini dilakukan dengan cara melakukan pretest $\left(\mathrm{T}^{1}\right)$ sebelum diberi latihan menyikat gigi (X) dan melakukan posttest $\left(\mathrm{T}^{2}\right)$ setelah diberi latihan menyikat gigi. Treatment dilakukan sebanyak 8 kali dalam 8 kali pertemuan.

Populasi pada penelitian ini adalah seluruh siswa SD di SLB-C Pancaran Kasih Cirebon yang mengalami Tunagrahita yang berjumlah 45 orang anak. Teknik pengambilan sampel pada penelitian ini menggunakan purposive sampling. Pengambilan sampel secara purposive didasarkan pada suatu pertimbangan tertentu yang dibuat oleh peneliti sendiri, berdasarkan ciri atau sifat-sifat populasi yang sudah diketahui sebelumya. Sampel pada penelitian ini berjumlah 10 orang anak. Data diperoleh dengan cara observasi dan dianalisis secara statistika menggunakan analisa uji paired t-test, dengan tingkat signifikasi 0,05 . 
Pada penelitian ini analisa univariat meliputi variabel dependen yaitu pemberian latihan menyikat gigi. Analisis bivariat dalam penelitian ini adalah untuk menguji pengaruh pemberian latihan menyikat gigi terhadap kemampuan menyikat gigi pada anak tunagrahita. Uji normalitas data dilakukan untuk mengetahui data terdistribusi normal atau terdistribusi tidak normal sehingga peneliti mampu menentukan uji statistik yang tepat. Pada penelitian ini uji normalitas menggunakan adalah Saphiro Wilk dikarenakan jumlah sampel kurang dari 50.

\section{HASIL PENELITIAN Karakteristik}

Tabel 1. Karakteristik Umum

\begin{tabular}{cccc}
\hline No & Kategori & $\mathrm{n}=10$ & Persentase $(\%)$ \\
\hline 1 & & 40 \\
& Usia & 4 & 20 \\
& 8 Tahun & 2 & 30 \\
& 9 Tahun & 3 & 10 \\
\hline 10 Tahun & 1 & \\
\hline 11 Tahun & & 70 \\
\hline 3 & Jenis Kelamin & 7 & 30 \\
\hline & Laki-laki & 3 & 60 \\
\hline & Perempuan & & 20 \\
\hline
\end{tabular}

Pada tabel 1 responden paling banyak berusia 8 tahun yaitu 4 anak (40\%). Responden terbanyak yaitu berjenis kelamin laki-laki sebesar 7 anak (70\%). Responden berada di dua kelas yang berbeda dan responden terbanyak duduk di bangku kelas kelas 2 sebanyak 6 anak $(60 \%)$.

\section{Kemampuan Menyikat Gigi Pada Anak Tunagrahita}

Tabel 2. Distribusi Frekuensi Kemampuan Menyikat Gigi pada Anak Tunagrahita Sebelum Dilakukan Latihan Menyikat Gigi

\begin{tabular}{cccc}
\hline No & Kemampuan & n & Persentase (\%) \\
\hline 1 & Kurang mampu & 10 & 100 \\
2 & Mampu & 0 & 0 \\
\hline \multicolumn{2}{c}{ Total } & 10 & 100 \\
\hline
\end{tabular}

Pada tabel 2 dapat dilihat bahwa distribusi frekuensi kemampuan menyikat gigi pada anak tunagrahita sebelum dilakukan latihan menyikat gigi yaitu seluruh responden berjumlah 10 anak (100\%) kurang mampu.

Tabel 3. Distribusi Frekuensi Kemampuan Menyikat Gigi pada Anak Tunagrahita Setelah Dilakukan Latihan Menyikat Gigi

\begin{tabular}{cccc}
\hline No & Kemampuan & n & Persentase (\%) \\
\hline 1 & Kurang mampu & 4 & 40 \\
2 & Mampu & 6 & 60 \\
\hline & Total & 10 & 100 \\
\hline
\end{tabular}


Berdasarkan tabel 3 dapat dilihat bahwa distribusi frekuensi kemampuan menyikat gigi pada anak tunagrahita setelah dilakukan latihan menyikat gigi yaitu terdapat 6 anak $(60 \%)$ mampu menyikat gigi dengan benar.

\section{Pengaruh Latihan Menyikat Gigi Terhadap Kemampuan Menyikat Gigi Pada Anak Tungrahita}

Tabel 4. Pengaruh Latihan Menyikat Gigi Terhadap Kemampuan Menyikat Gigi

\begin{tabular}{cccc}
\hline Kemampuan Menyikat Gigi & Mean & Standar Deviasi & P value \\
\hline Sebelum & 16,60 & 1,174 & 0,000 \\
Sesudah & 20,10 & 2,331 & \\
\hline
\end{tabular}

Pada tabel 4 menunjukkan hasil pengujian hipotesis menunjukkan bahwa sebelum diberikan pelatihan menyikat gigi pada kondisi awal (pretest) didapatkan nilai rata-rata kemampuan 16,60 (SD=1,174). Setelah dilakukan pelatihan menyikat gigi didapatkan nilai rata-rata menjadi $20,10(\mathrm{SD}=2,331)$, pernyataan ini berarti terjadi peningkatan skala rata-rata kemampuan sebesar 3,5. Berdasarkan uji t-test, diketahui bahwa nilai probabilitas (sig) korelasi antara kemampuan menyikat gigi sebelum dan sesudah dilakukan laihan menyikat gigi sebesar $0,000<0,05$ menunjukan hubungan yang signifikan.

\section{PEMBAHASAN}

\section{Kemampuan Menyikat Gigi pada Anak Tunagrahita Sebelum Dilakukan Latihan Menyikat Gigi Di SLB C}

Berdasarkan hasil penelitian yang dilakukan terhadap 10 anak tunagrahita untuk mengetahui kemampuan menyikat gigi sebelum dilakukan intervensi latihan menyikat gigi yang tertera pada table 2 menunjukan seluruh anak tunagrahita sedang yang dijadikan responden yaitu sebanyak 10 anak (100\%) kurang mampu menyikat gigi dengan benar.

Pada penelitian ini seluruh anak tidak mampu melakukan sikat gigi dengan benar, kondisi ini disebabkan karena kurangnya perhatian orang tua dalam memantau kegiatan menyikat gigi pada anak-anaknya serta kurangnya kesadaran anak akan pentingnya menyikat gigi dan juga disebabkan karena kondisi fisik dan keterlambatan perkembangan kecerdasan membuat anak tidak mengerti dengan baik apa itu menyikat gigi dan sulit dalam melakukannya. Oleh karena itu sebaiknya orang tua senantiasa memperhatikan kebersihan diri anak, salah satunya yaitu dalam kegiatan menyikat gigi dan mengajarkan anak bagaimana cara menyikat gigi yang benar seperti yang tercantum dalam leaflet yang diberikan.

\section{Kemampuan Menyikat Gigi pada Anak Tunagrahita Setelah Dilakukan Latihan Menyikat Gigi Di SLB C}

Berdasarkan hasil penelitian yang dilakukan terhadap 10 anak tunagrahita untuk mengetahui kemampuan menyikat gigi setelah dilakukan intervensi latihan menyikat gigi yang tertera pada tabel 3 menunjukan terjadi peningkatan kemampuan menyikat gigi. Dimana terdapat 6 anak (60\%) mampu menyikat gigi dengan benar .

Kondisi ini dipengaruhi oleh beberapa faktor diantaranya muncul kesadaran anak akan pentingnya menyikat gigi untuk kesehatan gigi dan mulut, dan muncul rasa tertarik untuk melakukan kegiatan menyikat gigi terus menerus. Pengaruh latihan menyikat gigi pada anak tunagrahita menyebabkan kemampuan siswa menjadi bertambah dan lebih peduli dalam menjaga kebersihan gigi dan mulut. 


\section{Pengaruh Latihan Menyikat Gigi Terhadap Kemampuan Menyikat Gigi Pada Anak Tunagrahita Di SLB C}

Berdasarkan hasil penelitian setelah diberikan pelatihan menyikat gigi pada kondisi awal (pretest) didapatkan nilai rata-rata kemampuan 16,60 $(\mathrm{SD}=1,174)$. Setelah dilakukan pelatihan menyikat gigi didapatkan nilai rata-rata menjadi $20,10(\mathrm{SD}=2,331)$, pernyataan ini berarti terjadi peningkatan skala rata-rata kemampuan sebesar 3,5. Berdasarkan uji t-test, diketahui bahwa $t_{\text {hitung }}-7,720>t_{t a b e l}-2,262$ dan nilai probabilitas (sig) korelasi antara kemampuan menyikat gigi sebelum dan sesudah dilakukan laihan menyikat gigi sebesar 0,000 $<0,05$ menunjukan hubungan yang signifikan.

Dari hasil uji $\mathrm{t}$ dan nilai probabilitas (sig) mengindikasikan $\mathrm{H}_{0}$ ditolak dan $\mathrm{H}_{\mathrm{a}}$ diterima atau ada pengaruh latihan menyikat gigi terhadap kemampuan menyikat gigi pada anak tunagrahita di SLB C Pancaran Kasih Tahun 2017.

Selain itu dapat dilihat dari hasil perbedaan hasil pretest menunjukan keseluruhan responden kurang mampu menyikat gigi dengan benar sejumlah 10 anak (100\%). Sedangkan hasil post test menunjukan peningkatan bahwa 6 anak (60\%) sudah mampu menyikat gigi dengan benar.

Dari hasil kedua uji statistik diatas dapat dikatakan bahwa latihan menyikat gigi berpengaruh terhadap kemampuan menyikat gigi pada anak tunagrahita di SLB C Pancaran Kasih Tahun 2017. Disarankan kepada orang tua dan guru untuk dapat terus memberikan dukungan dan melatih anak untuk dapat melakukan aktivitas sehari-sehari secara mandiri khususnya pada kegiatan menyikat gigi.

\section{SIMPULAN}

1. Sebelum dilakukannya latihan menyikat gigi didapatkan hasil bahwa seluruh responden sebesar 10 anak (100\%) kurang mampu menyikat gigi dengan benar.

2. Setelah dilakukannya latihan menyikat gigi didapatkan hasil bahwa sebanyak 6 anak (60\%) sudah mampu menyikat gigi dengan benar.

3. Terdapat perbedaan rata-rata kemampuan menyikat gigi sebelum latihan sebesar 16,60 dan setelahlatihan menyikat gigi sebesar 20,10 dengan $t_{\text {hitung }}-7,720>t_{\text {tabel }}-2,262$ serta nilai probabilitas (sig) korelasi sebesar $0,000<0,05$, maka $\mathrm{H}_{0}$ ditolak dan $\mathrm{H}_{\mathrm{a}}$ diterima yang artinya ada pengaruh latihan menyikat gigi terhadap kemampuan menyikat gigi pada anak tunagrahita di SLB C Pancaran Kasih Kota Cirebon tahun 2017.

\section{SARAN}

\section{Bagi SLB C}

Kepada pihak sekolah disarankan untuk membuat jadwal kegiatan menyikat gigi diluar pelajaran bina diri yang bisa dilakukan secara bersama-sama dan sebaiknya dikelas terdapat gambar-gambar atau poster tentang kegiatan menyikat gigi.

2. Bagi Orang Tua

Disarankan kepada orang tua untuk tetap dapat memberikan dukungan dan melatih anak untuk dapat melakukan aktivitas sehari-sehari secara mandiri khususnya pada kegiatan menyikat gigi, mengingat cara melakukannya sangat sederhana dan mudah serta bermanfaat untuk dirinya sendiri sehingga dapat dilakukan latihan menyikat gigi lebih banyak lagi di dalam rumah.

3. Bagi Stikes Cirebon

Stikes Cirebon perlu mengembangkan kurikulum mata kuliah keperawatan anak khususnya dalam memberikan materi pembelajaran mengenai anak berkebutuhan khusus sehingga, perawat dapat melakukan tindakan untuk meningkatkan kemandirian anak berkebutuhan khusus. 


\section{Bagi Perawat}

Hasil penelitian ini menunjukan ada pengaruh pemberian latihan menyikat gigi terhadap kemampuan menyikat gigi pada anak tunagrahita sehingga penyuluhan menyikat gigi dapat direkomendasikan sebagai tindakan alternatif perawat komunitas dalam menjaga kebersihan gigi dan mulut serta disarankan kepada perawat untuk dapat mengembangkan metode pelatihan lainnya dalam meningkatkan kemampuan untuk melakukan aktivitas sehari-hari anak berkebutuhan khusus.

5. Bagi Peneliti Selanjutnya

Diharapkan peneliti selanjutnya dapat mengembangkan penelitian tentang kemandirian pada anak berkebutuhan khusus pada aspek aktivitas kegiatan harian yang lainnya dengan melibatkan keluarga dan juga disarankan untuk peneliti selanjutnya untuk melakukan penelitian tentang peran pendidik terhadap kemandirian pada anak berkebutuhan khusus dalam melakukan aktivitas sehari-hari (activity of daily living).

\section{DAFTAR PUSTAKA}

1. Wikipedia. Anak berkebutuhan khusus. [diunduh pada tanggal 6 November 2016]. Tersedia dari: https://id.wikipedia.org

2. Rini Andriani. Pengertian anak berkebutuhan khusus (ABK). [diunduh pada 6 November 2016]. Tersedia dari: http://www.membumikanpendidikan.com

3. Mujaddid. Situasi penyandang disabilitas (kesehatan anak dengan disabilitas). Jakarta. 2014

4. Kementerian Sosial Republik Indonesia. Angka pembangunan kesejahteraan sosial. Jakarta: Kemensos; 2012

5. Siswanto. Pendidikan kesehatan anak usia dini. Yogyakarta: Pustaka; 2010

6. Notoatmojo, Soekidjo. Metodologi penelitian kesehatan. Jakarta: Rineka Cipta; 2012

7. Arikunto, Suharsimi. Prosedur penelitian suatu pendekatan praktik (Edisi Revisi VI). Jakarta: Rineka Cipta; 2006 